\title{
BRIEF STUDY ON THE DECOMPOSITION OF TETRAETHYLENE GLYCOL DIMETHYL ETHER (TEGDME) SOLVENT IN THE PRESENCE OF $\mathrm{Li}_{2} \mathrm{O}_{2} \mathrm{AND}_{2} \mathrm{O}_{2}$
}

\author{
PAULINA MÁRQUEZ ${ }^{a, b^{*}}$, MAURICIO MONCADA-BASUALTO ${ }^{c}$, CLAUDIO OLEA-AZAR $^{c}$, \\ FRANCISCO HERRERA ${ }^{d}$, MACARENA GARCÍA ${ }^{e}$ AND MARÍA J. AGUIRRE ${ }^{d^{*}}$ \\ ${ }^{a}$ Departamento de Física, Universidad de Santiago de Chile, Av. B. O'Higgins 3363, Estación Central, Santiago, Chile. \\ ${ }^{b}$ Center for the Development of Nanoscience and Nanotechnology, Av. B. O'Higgins 3363, Estación Central, Santiago, Chile. \\ ${ }^{c}$ Laboratory of Free Radicals and Antioxidants. Faculty of Chemical and Pharmaceutical Sciences, University of Chile, \\ Sergio Livingstone Polhammer 1007, Independencia, Santiago, Chile. \\ ${ }^{d}$ Departamento de Química de los Materiales, Facultad de Química y Biología, Universidad de Santiago de Chile, Av. B. O'Higgins 3363, \\ Estación Central, Santiago, Chile. \\ ${ }^{e}$ Laboratorio de Procesos Fotónicos y Electroquímicos, Departamento de Ciencias y Geografía, Universidad de Playa Ancha, Valparaíso, Chile.
}

\begin{abstract}
In this work, the decomposition of the solvent tetraethylene glycol dimethyl ether (TEGDME) was studied under conditions that simulate the charge of a Li- ${ }_{2}$ cell in the presence and absence of hydrogen peroxide and lithium peroxide by means of electron spin resonance spectroscopy (ESR). We detected the formation of radical species, although in low concentrations, originating from solvent decomposition reactions during the oxidation process, in the absence of peroxides. On the other hand, by introducing $\mathrm{H}_{2} \mathrm{O}_{2}$ and $\mathrm{H}_{2} \mathrm{O}$ into the system, oxygen-centered superoxide and hydroxyl radical species were detected. Furthermore, in the presence of $\mathrm{Li}_{-} \mathrm{O}_{2}$, carbon-centered radical species were detected which clearly show the decomposition of the solvent. Finally, the results show that it is very important that the charging process of a $\mathrm{Li}-\mathrm{O}_{2}$ cell is carried out by direct oxidation via $2 \mathrm{e}^{-}$to $\mathrm{Li}_{2} \mathrm{O}_{2}$ to avoid the formation of radical species that the decomposition of the solvent.
\end{abstract}

Keywords: Carbon-centered radicals, $\mathrm{Li}-\mathrm{O}_{2}$ cell, oxygen-centered radicals, hydrogen peroxide, lithium peroxide, tetraethylene glycol dimethyl ether decomposition.

\section{INTRODUCTION}

Lithium-air batteries stand out for their high density compared to the existing lithium-ion battery technology. Despite their promising future, these systems are still in a research stage, due to their limited cyclability as a result of parasitic reactions that occur between the cathode and the electrolyte during the successive charging and discharging processes [1]. These products come more specifically from decomposition of solvent [2], electrolyte [3, 4], the carbon [5] and the binder [6]. These unwanted reactions decrease the capacity and efficiency of the battery. One of the biggest challenges these days has been finding a suitable solvent for these electrolytic systems. An ideal solvent should have high stability, low vapor pressure and adequate oxygen solubility [4]. In summary, an ideal solvent for $\mathrm{Li}-\mathrm{O}_{2}$ systems must meet the following requirements:

- Stability against metallic lithium, as it is used as an anode during the discharge process and as a cathode in the charging process;

- High boiling point and low volatility because it is an open cell system;

- High solubility and diffusivity of oxygen to facilitate oxygen reduction and oxygen evolution reactions at the carbon electrode;

- Low viscosity to improve oxygen electrode performance.

Among the solvents that have been used are carbonates and ethers [7-12]. Tetraethyleneglycol dimethyl ether (TEGDME) has a higher stability to the oxygen reduction products generated in the lithium air cell discharge process compared to carbonate-based solvents and also has a lower vapor pressure than dimethyl ether (DME), another ether used as a solvent in Li-air batteries, which allows to solve the problem of electrolyte evaporation [13]. These qualities have allowed this solvent to be widely used in lithium air cells [13-17] today. Table 1 shows the physicochemical properties of the TEGDME solvent.

Table 1. Physical properties of TEGDME aprotic solvent [14].

\begin{tabular}{|c|c|c|c|c|c|c|}
\hline Solvent & \begin{tabular}{|c|}
$\begin{array}{c}\text { Molecular } \\
\text { weight } \\
\mathrm{g} \mathrm{mol}^{-1}\end{array}$ \\
\end{tabular} & Str & $\begin{array}{c}\text { Viscosity } \\
\eta \\
\left(\mathbf{C p}, 25^{\circ} \mathrm{C}\right) \\
\end{array}$ & \begin{tabular}{|c|}
$\begin{array}{c}\text { Oxygen } \\
\text { Solubility } \\
\left(\mathrm{mM} \mathrm{cm}^{-3}\right)\end{array}$ \\
\end{tabular} & 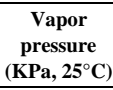 & $\begin{array}{c}\begin{array}{c}\text { Donor } \\
\text { number } \\
\left(\text { kcal mol }^{-1}\right)\end{array} \\
\end{array}$ \\
\hline TEGDME & 222 & & 4.05 & 4.43 & $<1.33$ & 16.6 \\
\hline
\end{tabular}

However, although TEGDME is more suitable than other solvents based on ether or carbonates of lower molecular weight, is not totally stable in the presence of peroxides and in the oxidation potential range of the latter, as will be seen later.
On the other hand, the oxygen reduction and evolution reaction in aprotic systems with lithiated salts exhibit a different response to that of aprotic systems containing other types of salts. When using a bulky cation like $\mathrm{TBA}^{+}$ (tetrabutylammonium), a highly reversible process is observed, where the electronic transfer is through one electron $\left(\mathrm{O}_{2}+1 \mathrm{e}^{-} \leftrightarrow \mathrm{O}_{2}{ }^{\bullet}\right)$ [14, 15, 18]. However, in $\mathrm{Li}-\mathrm{O}_{2}$ cells, where salts containing an alkali metal as a cation (for example, $\mathrm{LiClO}_{4}$ ) are used, more complex electrochemical processes are observed with a quasi-reversible or irreversible behavior [18, 19]. Thus, it has been described that the reduction of oxygen can lead to the formation of superoxide $\left(\mathrm{O}_{2}{ }^{-}\right)$, peroxide $\left(\mathrm{O}_{2}^{-2}\right)$ and/or oxide $\left(\mathrm{O}^{-2}\right)$. This difference in mechanisms is explained by Pearson's theory of hard soft acid base (HSAB) $[15$, 16, 18]. This theory states that hard acids prefer hard bases and that soft bases prefer soft acids. Hard cations such as $\mathrm{Li}^{+}$have a higher affinity for hard species such as peroxide and oxide, which are classified as Lewis hard bases, unlike superoxide ion, which due to its large relative radius and low charge density, is classified as a moderately base [15], so this ion does not stabilize in this type of system. However, these interactions can be adjusted according to the basicity and acidity of each aprotic solvent, therefore, the strength of these interactions and even the reaction products can be strongly affected [20]. The basicity can be determined according to the Goutman donor number, DN and the acidity according to the acceptor number, AN [15, 20,21]. A solvent with a high basicity (high donor number) will solvate a hard acid such as lithium $\left(\mathrm{Li}^{+}-(\text {solvent })_{\mathrm{n}}\right)$, and in this way it is possible to reduce the acidity of the $\mathrm{Li}^{+}$cation, which would facilitate the formation and stabilization of species such as $\mathrm{LiO}_{2}$ in solution [15].

In the case of solvents with a low donor number, the formation of $\mathrm{LiO}_{2}$ adsorbed on the electrode surface is facilitated. These intermediate species, adsorbed on the electrode surface or in solution, undergo a second electron transfer to form solid $\mathrm{Li}_{2} \mathrm{O}_{2}$. Regarding the stability of anions as superoxide $\mathrm{O}_{2}$, they tend to stabilize better with solvents with high AN value than with solvents with low AN [20].

In the case of the solvent used in this work, TEGDME, it has a low DN value corresponding to $16.6 \mathrm{kcal} \mathrm{mol}^{-1}[15]$ and an $\mathrm{AN}$ of $10.5 \mathrm{kcal} \mathrm{mol}^{-1}$ [15] (see Table S1) [15, 22].

The different reactions of the discharge (Eq. 1-3) and charge (Eq. 4) processes of a $\mathrm{Li}-\mathrm{O}_{2}$ cell are shown below:

$$
\begin{array}{ll}
\mathrm{O}_{2}+\mathrm{Li}^{+}+\mathrm{e}^{-} \rightarrow \mathrm{LiO}_{2 \text { (ads or sol) }} & \text { (Eq. 1) } \\
\mathrm{LiO}_{2 \text { (ads) }}+\mathrm{Li}^{+}+\mathrm{e}^{-} \rightarrow \mathrm{Li}_{2} \mathrm{O}_{2} & \text { (Eq. 2) } \\
\mathrm{LiO}_{2 \text { (sol) }}+\mathrm{LiO}_{2 \text { (sol) }} \rightarrow \mathrm{Li}_{2} \mathrm{O}_{2}+\mathrm{O}_{2} \\
\mathrm{Li}_{2} \mathrm{O}_{2} \rightarrow \mathrm{O}_{2}+2 \mathrm{Li}^{+}+2 \mathrm{e}^{-}
\end{array}
$$


Some of the species generated during $\mathrm{Li}-\mathrm{O}_{2}$ cell operating processes are highly reactive and can cause solvent decomposition. Charging processes, compared to discharge processes, tend to be even more complex and also require high overcharging potentials $(>1 \mathrm{~V})$, which leads to low round-trip efficiency in the battery [23]. The mechanism of the charging process of $\mathrm{Li}_{2} \mathrm{O}_{2}$ generated during discharge is not yet clear and the type of species formed is under debate [23, 24].

To determine whether, under the operating conditions of a Li-air battery, the TEGDME solvent undergoes decomposition reactions during the charging process, a study was carried out using the electronic spin resonance technique (ESR), which allows characterizing the formation of radical species through the use of a spin trap, which increases the lifetime of the radical generated, thus facilitating the detection of this species. On the other hand, through this study it is possible to analyze the stability of the solvent in an isolated way, since, together with the cathodic mixture, it is much more complex to analyze the contribution to the generation of parasitic species as a result of the decomposition of the solvent, because, as mentioned above, several factors contribute to the generation of unwanted species during the operation of a $\mathrm{Li}_{-} \mathrm{O}_{2}$. In this study, the 5,5-dimethyl-1-pyrroline-N-oxide molecule, DMPO, was used as a spin trap.

\section{EXPERIMENTAL}

\section{Reagents:}

TEGDME (98\% purity) (dried over 3 Å molecular sieves), Lithium perchlorate battery grade (99.99\% purity) and 5,5-dimethyl-1-pyrroline-N-oxide (DMPO) ( $97 \%$ purity) were obtained from Sigma-Aldrich. Merck hydrogen peroxide (30\% w/w in water) was standardized by titration against acidified potassium permanganate solution that was prepared prior to use and standardized against anhydrous disodium oxalate. Sulfuric acid p.a. (95-97\%) was obtained from Merck. High purity nitrogen (99.999\%) (AGA) was used in the electrochemical experiments. Ultra pure water $(18 \mathrm{M} \Omega)$ was used.

\section{Electrodes:}

A platinum electrode was used as the working electrode, a platinum wire as the auxiliary electrode, and $\mathrm{Pt} / / \mathrm{Ag} / \mathrm{AgCl}$ was used as the reference electrode. This reference electrode was calibrated with reference to the ferrocenium/ferrocene couple $\left(\mathrm{Fc}^{+} / \mathrm{Fc}\right)$. The electrochemical activation treatment of the working electrode was carried out in a $0.5 \mathrm{M} \mathrm{H}_{2} \mathrm{SO}_{4}$ solution at $500 \mathrm{mV} \mathrm{s}$ ${ }^{1}$ between $-0.2 \mathrm{~V}$ y $1.3 \mathrm{~V}$.

\section{Electrochemical measurements}

Voltammetric responses were performed using a CHI 604C Electrochemical Analyzer Potentiostat between $-0.6 \mathrm{~V}$ and $0.7 \mathrm{~V}$. Responses were obtained in a nitrogen atmosphere at room temperature using a three-electrode cell in absence of oxygen or water. The measurements in the presence of $\mathrm{H}_{2} \mathrm{O}_{2}$ were carried out with the presence of water because this reagent comes in an aqueous medium. $0.1 \mathrm{M}$ lithium perchlorate in TEGDME was used as supporting electrolyte. Hydrogen peroxide oxidation-reduction studies were performed by adding an aliquot of $10 \mu \mathrm{L}$ of $\mathrm{H}_{2} \mathrm{O}_{2}(30 \% \mathrm{w} / \mathrm{w})$ in $10 \mathrm{~mL}$ of TEGDME with $0.1 \mathrm{M}$ lithium perchlorate $\left(9.8 \mathrm{mM} \mathrm{H}_{2} \mathrm{O}_{2}\right)$. Oxidation-reduction studies of lithium peroxide in $10 \mathrm{mM}$ of $\mathrm{Li}_{2} \mathrm{O}_{2}$ were performed with TEGDME and $0.1 \mathrm{M}$ lithium perchlorate.

\section{ESR spectroscopy:}

ESR spectra were recorded in the $\mathrm{X}$ band $(9.85 \mathrm{GHz})$ using a $50 \mathrm{KHz}$ field modulation in a Bruker ECS 106 spectrometer with a rectangular cavity. The hyperfine splitting constants were estimated to be accurate within $0.05 \mathrm{G}$. The radicals were generated by in situ electrolytic oxidation $(0.4 \mathrm{~V})$ under the same conditions of temperature, atmosphere and concentrations stated for the $\mathrm{CV}$ experiment and $200 \mathrm{mM}$ DMPO were added as a spin trap.

\section{RESULTS AND DISCUSSION}

To perform the measurements under conditions that simulate the charging process, it is necessary to determine the oxidation potential of $\mathrm{Li}_{2} \mathrm{O}_{2}$, and then use that potential and apply it during the characterization of radical species through ESR. For this reason, an electrochemical characterization is carried out using the cyclic voltammetry technique in a solution of $\mathrm{H}_{2} \mathrm{O}_{2}$ in $0.1 \mathrm{M}$ $\mathrm{LiClO}_{4} / \mathrm{TEGDME}$, using a platinum electrode as a working electrode, taking into account that the ESR technique also uses platinum as working electrode.
Both $\mathrm{H}_{2} \mathrm{O}_{2}$ and $\mathrm{Li}_{2} \mathrm{O}_{2}$ are used in the experiment. The latter is highly insoluble in the electrolyte used and, in addition to its properties as an insulating material, it has a highly resistive voltammetric profile and a fairly weak oxidation signal (See Figure 1, inset). Therefore, the signals obtained in the presence of $\mathrm{H}_{2} \mathrm{O}_{2}$ and in the presence of $\mathrm{Li}_{2} \mathrm{O}_{2}$ are compared, finding that, although the $\mathrm{Li}_{2} \mathrm{O}_{2}$ peak is very small due to its insolubility, the potential at which appears is the same at which $\mathrm{H}_{2} \mathrm{O}_{2}$ is oxidized, see Figure 1 .

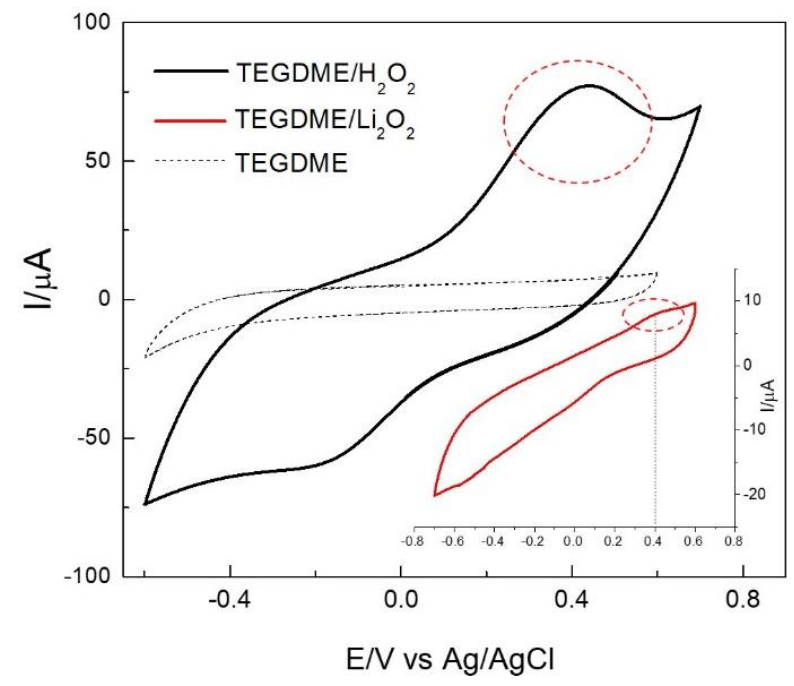

Figure 1. Voltammetric profile of platinum electrode in absence (black dotted line) and in presence of $9.8 \mathrm{mM} \mathrm{H}_{2} \mathrm{O}_{2}$ (solid black line). Inset corresponds to the voltametric profile of platinum in presence of $10 \mathrm{mM} \mathrm{Li}_{2} \mathrm{O}_{2}$ (solid red line). Red dotted line circle indicates oxidation process. For all systems $0.1 \mathrm{M}$ $\mathrm{LiClO}_{4} /$ TEGDME was used as electrolyte. Scan rate of $100 \mathrm{mV} \mathrm{s}^{-1}$.

Through the voltammograms of Figure 1 it is possible to obtain the oxidation potential of both peroxides, which correspond to $0.40 \mathrm{~V}$. This is the potential used for the electro-oxidation of $\mathrm{Li}_{2} \mathrm{O}_{2}$ through ESR.

The characterization of the radical species generated by in-situ electrochemical oxidation in an aprotic medium is carried out by applying the potential determined by cyclic voltammetry. Spectra are recorded after 100 scans in the presence of $\mathrm{Li}_{2} \mathrm{O}_{2}$ and $\mathrm{H}_{2} \mathrm{O}_{2}$; using DMPO as a spin trap.

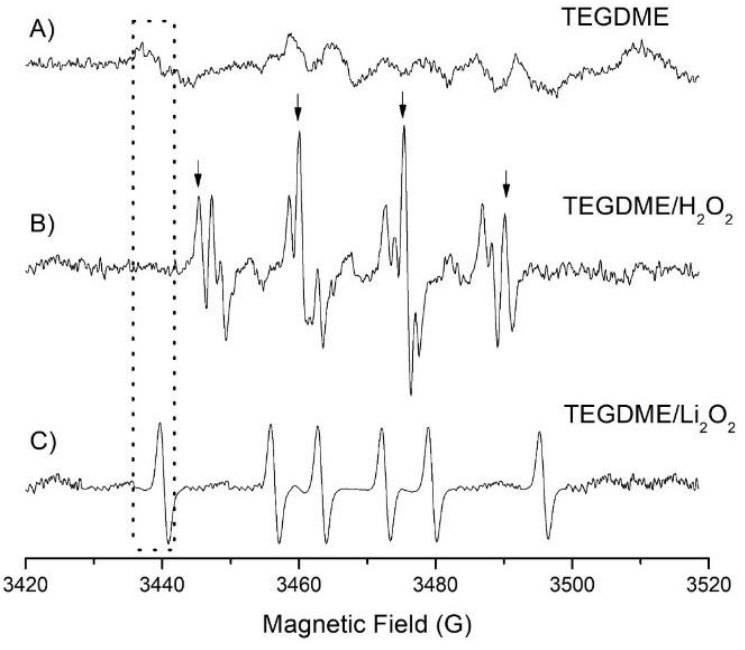

Figure 2. ERS spectra of TEGDME in the presence of A) $\left.0.1 \mathrm{M} \mathrm{LiClO}_{4}, \mathrm{~B}\right) 9.8$ $\mathrm{mM} \mathrm{H}_{2} \mathrm{O}_{2}$ in $0.1 \mathrm{M} \mathrm{LiClO}_{4}$ and C) $10 \mathrm{mM} \mathrm{Li}_{2} \mathrm{O}_{2}$ in $0.1 \mathrm{M} \mathrm{LiClO}_{4}$. The applied potential is $0.4 \mathrm{~V}$ for 100 scans.

Figure 2A) shows the ESR spectrum of the TEGDME solvent with $0.1 \mathrm{M}$ $\mathrm{LiClO}_{4}$ in the absence of $\mathrm{Li}_{2} \mathrm{O}_{2}$ and $\mathrm{H}_{2} \mathrm{O}_{2}$. As can be seen, low intensity signals appear that can be assigned to the hyperfine pattern of a carbon-centered radical [25]. This indicates that the solvent undergoes radical decomposition reactions when the oxidation potential $0.4 \mathrm{~V}$ is applied, without the presence of peroxide. 
However, the low intensity of the signals indicates a low concentration of the generated radical species.

In the presence of $\mathrm{H}_{2} \mathrm{O}_{2}$, Figure $2 \mathrm{~B}$ ), a different pattern is observed. This can be attributed to the trapping of the superoxide radical produced by the oxidation of $\mathrm{H}_{2} \mathrm{O}_{2}$ that first generates the formation of molecular oxygen $\left(\mathrm{H}_{2} \mathrm{O}_{2} \rightarrow \mathrm{O}_{2}+\right.$ $\left.2 \mathrm{H}^{+}+2 \mathrm{e}^{-}\right)$, which is secondly reduced to superoxide by the transfer of one electron $\left(\mathrm{O}_{2}+\mathrm{e}^{-} \rightarrow \mathrm{O}_{2}^{2^{-}}\right)$. Additionally, the formation of hydroxyl radical is corroborated by the presence of a characteristic intensity 1:2:2:1 pattern (marked with $\downarrow$ in Figure 2B) and that can be produced by a decomposition reaction of water $\left(\mathrm{H}_{2} \mathrm{O} \rightarrow \mathrm{OH} \cdot+\mathrm{H}^{+}+\mathrm{e}^{-}\right)$and $\mathrm{H}_{2} \mathrm{O}_{2}\left(\mathrm{H}_{2} \mathrm{O}_{2}+\mathrm{O}_{2}^{-} \rightarrow \mathrm{OH}+\mathrm{OH}^{-}+\mathrm{O}_{2}\right)$.

The spectrum of Figure 2C) is recorded in the presence of $\mathrm{Li}_{2} \mathrm{O}_{2}$. In this case, the profile obtained mainly shows a carbon-centered specie (see dotted line in Figure (2C)). This signal is not observed in the presence of hydrogen peroxide and is attributable to the decomposition of the solvent. The high intensity of the signals observed in TEGDME/ $\mathrm{Li}_{2} \mathrm{O}_{2}$ compared to blank (TEGDME, Figure 2A)) is indicative of an increase in the appearance of carbon-centered radical species suggesting that, in the presence of $\mathrm{Li}_{2} \mathrm{O}_{2}$, the formation of radical is favored by the decomposition of the solvent. One way to understand this phenomenon is by assuming the initial generation of a species of oxygen-centered radical that reacts with TEGDME solvent, through the transfer of an hydrogen atom, causing an increase in the concentration of carbon-centered radicals [26], as shown in Figure 3 , where a solvent decomposition mechanism is presented in the presence of $\mathrm{LiO}_{2}$ from the oxidation of $\mathrm{Li}_{2} \mathrm{O}_{2}$

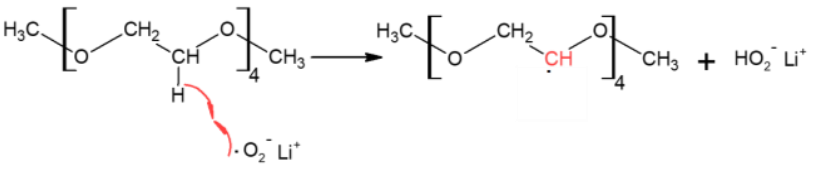

Figure 3. Mechanism for the generation of carbon-centered radical species, when the electro-oxidation of $\mathrm{Li}_{2} \mathrm{O}_{2}$ occurs in TEGDME

The results indicate that the generation of radical species from the decomposition of the solvent can be detected when the oxidation potential of the peroxide is applied, both in presence and in the absence of $\mathrm{Li}_{2} \mathrm{O}_{2}$. The species detected in the absence of $\mathrm{Li}_{2} \mathrm{O}_{2}$, corresponding to carbon-centered radical species, are attributed to the decomposition of the solvent. On the other hand, the species detected in the presence of $\mathrm{Li}_{2} \mathrm{O}_{2}$ are attributed to the natural decomposition of the solvent and the reaction shown in Figure 3. Likewise, the radicals formation observed could be attributed to singlet oxygen $\left({ }^{1} \mathrm{O}_{2}\right)[2,27$, 28 ], since it has recently, been experimentally demonstrated that there is the possibility that during the charging process in a $\mathrm{Li}-\mathrm{O}_{2}$ battery, ${ }^{1} \mathrm{O}_{2}$ is formed Furthermore, it has been proposed that this species can be produced from a disproportionation reaction of $\mathrm{LiO}_{2}\left(2 \mathrm{LiO}_{2} \rightarrow\left(\mathrm{LiO}_{2}\right)_{2} \rightarrow \mathrm{Li}_{2} \mathrm{O}_{2}+{ }^{1} \mathrm{O}_{2}\right)[27]$ or from source of protons (such as $\mathrm{H}_{2} \mathrm{O}$ ) that react with the $\mathrm{LiO}_{2}$-like surfaces according to: $2 \mathrm{O}_{2}^{-}+2 \mathrm{H}^{+} \rightarrow \mathrm{H}_{2} \mathrm{O}_{2}+{ }^{1} \mathrm{O}_{2}$ [27].

M. Carboni et al. [26], based on DFT calculations with an ether-based solvent, dimethoxyethane, DME, proposed that after the generation of ${ }^{1} \mathrm{O}_{2}$, this specie can cause the breaking of the slightly acidic $\mathrm{C}-\mathrm{H}$ bonds of the ether molecule, and that this breakdown would likely lead to the formation of carbon-centered radical molecules. Based on these antecedents, it can be inferred that the decomposition observed in the spectrum of Figure 2C) can be attributed directly to the attack of oxidized species of $\mathrm{Li}_{2} \mathrm{O}_{2}$, such as $\mathrm{LiO}_{2}$, and also, but indirectly, to reactions of ${ }^{1} \mathrm{O}_{2}$.

Regarding the carbon-centered radical species that were detected in the absence of $\mathrm{Li}_{2} \mathrm{O}_{2}$ (see Figure (2A)), the generation of these species would be associated with a auto-oxidation phenomenon, common in this type of solvents [1, 29-31].

In the case of lithium peroxide, the formation of carbon-centered radical species is found, attributable to the decomposition of the solvent. Likewise, no radical species centered on oxygen are detected, which is to be expected, since it has been proposed that the $\mathrm{Li}_{2} \mathrm{O}_{2}$ oxidation process can go well by a direct mechanism where an $2 \mathrm{e}^{-}$oxidation occurs without intermediate stages $\left(\mathrm{Li}_{2} \mathrm{O}_{2} \rightarrow\right.$ $\left.\mathrm{O}_{2}+2 \mathrm{e}^{-}+2 \mathrm{Li}^{+}\right)[32,33]$, or through a stepwise oxidation mechanism, obtaining as intermediate species $\mathrm{LiO}_{2}\left(\mathrm{Li}_{2} \mathrm{O}_{2} \rightarrow \mathrm{LiO}_{2}+1 \mathrm{e}^{-}+\mathrm{Li}^{+}\right)$or $\mathrm{Li}_{\mathrm{x}} \mathrm{O}_{2}\left(\mathrm{Li}_{2} \mathrm{O}_{2} \rightarrow \mathrm{Li}_{\mathrm{x}} \mathrm{O}_{2}\right.$ $+\mathrm{xe}^{-}+\mathrm{xLi}^{+}$) [34-38].

In the case of the study carried out with $\mathrm{H}_{2} \mathrm{O}_{2}$, the spectrum clearly shows the identification of superoxide and hydroxyl radicals, which indicates that the interactions between the solvent TEGDME and the oxidized species of $\mathrm{H}_{2} \mathrm{O}_{2}$ are different from those generated with $\mathrm{Li}_{2} \mathrm{O}_{2}$. A possible explanation could be associated with the presence of water in the case of the $\mathrm{H}_{2} \mathrm{O}_{2}$ study, since adding hydrogen peroxide also adds water to the system. When comparing the basicity of the solvent TEGDME and $\mathrm{H}_{2} \mathrm{O}$, both have a very close DN, 16.6 and $18.0 \mathrm{kca}$ $\mathrm{mol}^{-1}$, respectively, so it is not possible to attribute the differences found to this parameter, but when analyzing the acidity of both solvents depending on the acceptor number, $\mathrm{AN}, \mathrm{H}_{2} \mathrm{O}$ has a considerably higher value with respect to TEGDME (54.8 and $10.5 \mathrm{kcal} \mathrm{mol}^{-1}$ respectively) [39]. A higher acidity of the solvent allows the stabilization of anions such as $\mathrm{O}_{2}^{-}$, in this case, the $\mathrm{H}_{2} \mathrm{O}$ molecules promote the solvation of superoxide ion and, in turn, reduce the interactions between these species and TEGDME. However, the oxygencentered radical species that were detected could also come from an oxidation reaction of $\mathrm{H}_{2} \mathrm{O}\left(\mathrm{H}_{2} \mathrm{O} \rightarrow \mathrm{OH}^{\cdot}+\mathrm{H}^{+}+\mathrm{e}^{-}\right)$, so this additive in the electrolyte solution could induce more parasitic chemistry, as has been seen in other studies that use water as an additive, where only during the first cycle it is possible to observe high capacities and then a deterioration of the cell is observed as a result of the accumulation of unwanted species [40-42].

These results corroborate the instability of this ether-based solvent. During the charging process of $\mathrm{Li}-\mathrm{O}_{2}$ batteries, it is expected that the oxidation of $\mathrm{Li}_{2} \mathrm{O}_{2}$ will occur, according to the reaction shown in equation 4 , but based on the results obtained by the ERS technique, it can be inferred that in addition to this reaction, during the charging process, radical species would be formed as a result of the decomposition of the solvent. Therefore, the TEGDME solvent not only decomposes during discharge, as described by several authors [18, 30, 43] but also decomposes during charge, in the absence of carbon and catalyst, increasing surface poisoning in both processes, which result in low rechargeability. On the other hand, the incorporation of water into the system drastically modifies the species trapped by DMPO, indicating that there is an increase in radical species that would contribute to the decomposition of the solvent.

\section{CONCLUSIONS}

From the experiments carried out, it was possible to analyze the degradation of the TEGDME solvent under conditions that simulate a charging process of a $\mathrm{Li}-\mathrm{O}_{2}$ battery in the absence of interferents such as carbon and catalyst. From ESR studies it was possible to detect the formation of radical species, although in low concentrations, caused by decomposition reactions of the solvent during the oxidation process, in the absence of species such as peroxide. On the other hand, when $\mathrm{H}_{2} \mathrm{O}_{2}$ and $\mathrm{H}_{2} \mathrm{O}$ were introduced into the system, radical species centered on oxygen were detected; superoxide and hydroxyl, both species are highly reactive and therefore, these species in a $\mathrm{Li}-\mathrm{O}_{2}$ cell would contribute to the decomposition of the solvent. Then, in the presence of $\mathrm{Li}_{-} \mathrm{O}_{2}$, carbon-centered radical species were detected that clearly show the decomposition of the solvent Finally, the results show that the species generated during the oxidation of $\mathrm{Li}_{2} \mathrm{O}_{2}$ contribute to the degradation of the solvent, so it is essential to promote a direct oxidation mechanism via $2 \mathrm{e}^{-}$to obtain $\mathrm{O}_{2}$.

\section{ACKNOWLEDGEMENTS}

PM acknowledges Postdoctoral FONDECYT 3200392 project, MMB acknowledges FONDECYT Postdoctoral 3190449 project, MJA acknowledges FONDECYT 1160324 project and Dicyt-USACH, F.H. acknowledges FONDECYT 1131019 project.

\section{REFERENCES}

1. K. Chen, G. Huang, X. B Zhang, Chin. J. Chem. 39, 32-42 (2021).

2. M. S. Hong, H. R. Byon, Batteries Supercaps. 4 (2), 286-293 (2021)

3. M. Celik, Kizilaslan, M. Can, T. Cetinkaya, H.Akbulut, Electrochim. Acta, 371 (2021).

4. H. P. Guo; Luo, W. B.; J. Chen, S. L Chou, H. K Liu, J. Z Wang. Adv Sustainable Syst., 2, 1700183 (2018).

5. M.M.O. Thotiyl, S.A. Freunberger, Z.Q. Peng, P.G. Bruce, J. Am. Chem. Soc 135, 494 (2013).

6. B.D. McCloskey, A. Speidel, R. Scheffler, D.C. Miller, V. Viswanathan, J.S Hummelshoj, J.K. Norskov, A.C. Luntz, J. Phys. Chem. Lett. 3, 997 (2012).

7. K. R. Ryan, L. Trahey, B. J Ingram, A. K. Burrell, J. Phys. Chem. C, 116 (37), 19724-19728 (2012).

8. W. Xu, K. Xu, V.V. Viswanathan, S.A. Towne, J.S. Hardy, J. Xiao, D.H. Hu, D.Y. Wang, J.G. Zhang, J. Power Sources, 196, 9631 (2011)

9. S.A. Freunberger, Y. Chen, Z. Peng, J.M. Griffin, L.J. Hardwick, F. Bardé, P. Novák, P.G. Bruce, J. Am. Chem. Soc., 133, 8040 (2011).

10. J. Read, J. Electrochem. Soc., 153, A96 (2006) 
11. R. Younesi, M. Hahlin, M. Treskow, J. Scheers, P. Johansson, K. Edstrom, J. Phys. Chem. C, 116, 18597 (2012).

12. W. Xu, J.Z. Hu, M.H. Engelhard, S.A. Towne, J.S. Hardy, J. Xiao, J. Feng, M.Y. Hu, J. Zhang, F. Ding, M.E. Gross, J.G. Zhang, J. Power Sources, 215 240 (2012).

13. M. Z. Kufian, S. Ramesh, A. K. Arof, Opt. Mater., 120, 111418 (2021).

14. Z. Ma, X.X. Yuan, L. Li, Z.F. Ma, D.P. Wilkinson, L. Zhang, J.J. Zhang, Energy Environ. Sci. 8, 2144 (2015).

15. C.O. Laoire, S. Mukerjee, K.M. Abraham, E.J. Plichta, M.A. Hendrickson, J. Phys. Chem. C, 114, 9178 (2010).

16. S. Ferrari, E. Quartarone, C. Tomasi, M. Bini, P. Galinetto, M. Fagnoni, P. Mustarelli, J. Electrochem. Soc. 162, A3001 (2015).

17. C.O. Laoire, S. Mukerjee, E.J. Plichta, M.A. Hendrickson, K.M. Abraham, J. Electrochem. Soc. 158, A302 (2011).

18. B.D. McCloskey, C.M. Burke, J.E. Nichols, S.E. Renfrew, Chem. Commun. 51, 12701 (2015).

19. F.S. Gittleson, R.C. Sekol, G. Doubek, M. Linardi, A.D. Taylor, $P C C P, \mathbf{1 6}$, 3230 (2014).

20. L. Wang, Y. Zhang, Z. Liu, L. Guo, Z. Peng, GEE, 2, 186 (2017).

21. M.J. Trahan, I. Gunasekara, S. Mukerjee, E.J. Plichta, M.A. Hendrickson, K.M. Abraham, J. Electrochem. Soc.161, A1706 (2014).

22. A. Khetan, H. Pitsch, V. Viswanathan, J. Phys. Chem. Lett. 5, 2419 (2014).

23. T. Zhang, R. Amine, X. Bi, Y. Qin, M. Li, S. Al-Hallaj, F. Huo, J. Lu, K. Amine, J. Mater. Chem. A, 7,15615 (2019).

24. S.Y. Kang, Y.F. Mo, S.P. Ong, G. Ceder, Chem. Mater. 25, 3328 (2013).

25. B. Aguilera-Venegas, C. Olea-Azar, V.J. Aran, H. Speisky, Future Med. Chem. 5, 1843 (2013)

26. M. Carboni, A.G. Marrani, R. Spezia, S. Brutti, J. Electrochem. Soc. 165, A118 (2018).

27. N. Mahne, B. Schafzahl, C. Leypold, M. Leypold, S. Grumm, A. Leitgeb, Gernot A. Strohmeier, M. Wilkening, O. Fontaine, D. Kramer, C. Slugove, Sergey M. Borisov, Stefan A. Freunberger, Nat. Energy, 2, 17036 (2017).
28. J. Wandt, P. Jakes, J. Granwehr, H.A. Gasteiger, R.A. Eichel, Angew. Chem. Int. Ed. 55, 6892 (2016).

29. M. Park, H. Sun, H. Lee, J. Lee, J. Cho, Adv. Energy Mater. 2, 780 (2012).

30. S.A. Freunberger, Y.H. Chen, N.E. Drewett, L.J. Hardwick, F. Barde, P.G Bruce, Angew. Chem. Int. Ed. 50, 8609 (2011).

31. M.M.O. Thotiyl, S.A. Freunberger, Z.Q. Peng, Y.H. Chen, Z. Liu, P.G. Bruce, Nat. Mater. 12, 1049 (2013).

32. T. Ogasawara, A. Debart, M. Holzapfel, P. Novak, P.G. Bruce, J. Am. Chem. Soc. 128,1390 (2006).

33. Z. Peng, S.A. Freunberger, L.J. Hardwick, Y. Chen, V. Giordani, F. Barde, P. Novak, D. Graham, J.-M. Tarascon, P.G. Bruce, Angew. Chem. Int. Ed. 50, 6351 (2011).

34. T. Liu, J. P Vivek, E. W. Zhao, J. Lei, N.Garcia-Araez, C. P. Grey, Chem. Rev., 120 (14), 6558-6625 (2020).

35. B.M. Gallant, D.G. Kwabi, R.R. Mitchell, J.G. Zhou, C.V. Thompson, Y. Shao-Horn, Energy Environ. Sci. 6, 2518 (2013).

36. J. Yang, D. Zhai, H.-H. Wang, K.C. Lau, J.A. Schlueter, P. Du, D.J. Myers, Y.-K. Sun, L.A. Curtiss, K. Amine, PCCP, 15, 3764 (2013).

37. Y. Wang, N.-C. Lai, Y.-R. Lu, Y. Zhou, C.-L. Dong, Y.-C. Lu, Joule, 2, 2364 (2018).

38. S. Ganapathy, B.D. Adams, G. Stenou, M.S. Anastasaki, K. Goubitz, X.-F. Miao, L.F. Nazar, M. Wagemaker, J. Am. Chem. Soc. 136, 16335 (2014).

39. V. Gutmann, Coord. Chem. Rev. 18, 225 (1976).

40. Z. Guo, X. Dong, S. Yuan, Y. Wang, Y. Xia, J. Power Sources, 264, 1 (2014)

41. K.U. Schwenke, M. Metzger, T. Restle, M. Piana, H.A. Gasteiger, J. Electrochem. Soc. 162, A573 (2015).

42. Y.G. Zhu, Q. Liu, Y. Rong, H. Chen, J. Yang, C. Jia, L.-J. Yu, A. Karton, Y. Ren, X. Xu, S. Adams, Q. Wang, Nat. Commun., 8, 14308 (2017).

43. X.W. Gao, Y.H. Chen, L. Johnson, P.G. Bruce, Nat. Mater. 15, 882 (2016). 